\title{
Research and Practice on Innovation Platform Construction of College Students - Based on Team Bridge Function
}

\author{
Wang Jianfeng, Liu Yiqun* \\ School of Automotive Engineering \\ Harbin Institute of Technology \\ Weihai, China \\ *Corresponding Author: lyq.new@163.com
}

\author{
Zhang Weiping, Li Xue \\ School of Economics and Management \\ Harbin Institute of Technology \\ Weihai, China
}

\begin{abstract}
Strategic significance of innovation is obvious, and cultivation of college students' innovation capacity is a basic assignment of higher education. This paper discusses the construction of college students' scientific and technological innovation platform using team as the bridge. We made team as the bridge of innovation activities and platform. Provide material insurance and establish financial aid system. Arrange the instructor scientifically and increase publicity. Improve management system and incentive mechanism. The proposed methods were successfully applied to the HIT Racing Team. Practice research results show that college student team is beneficial to propel the construction of innovation platform and system. The proposed methods can enhance students' scientific and technological innovation capacity.
\end{abstract}

Keywords-scientific and technological innovation; platform construction; team bridge; innovative education

\section{INTRODUCTION}

Scientific and technological innovation should be put at a more significant place and the trump of building a world technology superpower should be blown at the new historical starting point of China's development [1]. President Xi Jinping has taken the innovation as the core part of national overall development since the Eighteenth Congress of the CPC, paid high attention to science and technological innovation and given rise to a series of new thoughts, new conclusions and new requirements. Government has put forward corresponding preferential and supporting policies to encourage scientific and technological innovation, continues to deepen the reform of scientific and technological innovation system, and keeps exploring new methods and ways to cultivate scientific and technological innovation capacity. The policies can provide powerful technological supports to improving scientific and technological innovation capacity, and promote country's progress and accelerating economy construction. In this paper, colleges and universities carry out multi-layered scientific and technological innovation, dedicating to cultivating and improving college students' relevant capabilities.

\section{Present Situation Analysis of University Students' INNOVATION PLATFORM}

For now, the Chinese economy is in an important period,

Project (BKQN201608) Supported by Harbin Institute of Technology at Weihai, and Project (HIT(WH)201601) Supported by the Scientific Research Foundation of Harbin Institute of Technology at Weihai. higher education is an important support of national economic development, the reform of higher education should match the needs of the development of country. Aiming at the need of creative talents of science and technology and higher education to carry out the reform of engineering education, scientific and technological innovation ability and system construction of exploration, strengthen the innovation of social drives and technology leadership. According to market demand analysis, the ability to innovate or create new things with existing knowledge and material is becoming an important measure of talent. Therefore, the ability of scientific and technological innovation to train college students has become the necessity of the development of university students themselves, the reform of education and the improvement of comprehensive national strength [2].

However, the current domestic college students innovative activities to carry out the imbalance, stays in the primary stage, the active participation of college students of scientific and technological innovation activities project is not much [3], on the one hand because of the college students learn the theoretical knowledge, focus on class and ignore the cultivation of scientific and technological innovation ability. At the same time, not enough attention and support scientific and technological innovation in colleges and universities focuses on the learning of college students' test scores. Weakening of scientific and technological innovation achievements, leads to the consciousness that college students to participate in scientific and technological innovation is not strong, and weak subjective initiative. Level of scientific and technological innovation activity organization planning, on the other hand, the good and bad are intermingled, the existing organization hard require students to take the phenomenon, campaigns can not reach the desired effect [4]. At the same time, the lack of platform provides equipment support for scientific and technological innovation activities, and lacks the practical environment to train and cultivate students' ability to innovate in science and technology.

\section{SIGNIFICANCE OF INNOVATION PLATFORM CONSTRUCTION BASED ON TEAM BRIDGE FUNCTION}

With the advent of the knowledge economy, a variety of new knowledge, new technologies are emerging in an endless 
stream. Nowadays the scientific research, scientific and technological innovation require more team work. The individuals ability has become increasingly unable to cope with the complexity of the environment, and yet difficult to deal with the problem efficiently. Team has not only become a necessary way of scientific research, but also an important way in scientific and technological innovation. Taking team as a bridge to link the technological innovation activities and platform is benefit to organic combination of personal advantages, all-round considerations, brainstorm, the new ideas of scientific and technological innovation, the breaking of limitations of personal thinking, rational use of each member's knowledge and skills, realization of the advantages of complementary members, multi-faceted joint scientific and technological innovation and achievement of common goals.

College students organize this bridge through the team; you can use the platform of scientific and technological innovation more effectively. To promote the organic integration of classroom learning and extracurricular practice $[5,6]$ and to cultivate their innovative research and explore the habit of increasing their awareness of innovation and improve their ability to innovate. The use of the bridge between the team organization and the establishment of the university student science and technology innovation platform can also mobilize the enthusiasm of teachers and students' innovation and entrepreneurship, and promote the common development of various disciplines of various disciplines, which can contribute to the breakthrough of teaching mode development and deepen the teaching reform, as well as realize a win-win situation.

The construction of university scientific and technological innovation platform combines the technological innovation activities with the creative talents training, which can promote the school teaching work from the emphasis on knowledge transfer to the more emphasis on the ability and quality of the training to promote the reform of personnel training model; platform and traditional organizational structure The parallelism also provides support and guarantee for teachers and students to pursue academic excellence, strengthens the research and innovation ability of colleges and universities, effectively improves the quality of personal training, and lay a solid foundation for cultivating innovative application talents and enhancing the scientific and technological innovation ability of college students.

\section{RESEARCH OF INNOVATION PLATFORM CONSTRUCTION FOR COLleGE STUDENTS}

The establishment of university scientific and technological innovation platform for college students to provide a more systematic guidance for scientific and technological innovation, so that college students no longer stay in the theoretical research and practice support. Platform for college students to carry out autonomous learning, scientific and technological innovation and practice, is a teacher and student interaction, to the project process management as the core, to independent practice, research learning as the main form of innovative practice environment, to promote innovation and entrepreneurship education in colleges and universities the full implementation of the teaching work [7]. To create a platform for scientific and technological innovation of university students, the specific content is as follows:

\section{A. Provide material insurance and establish financial aid system}

The development of university students' scientific and technological innovation ability requires the strong support of colleges and universities, the construction of scientific and technological innovation platform for universities, the creation of conditions for the development of scientific and technological innovation platform, the provision of strong financial support, the provision of suitable venues for the daily activities of scientific and technological innovation, places and equipment to participate in scientific and technological innovation activities of teachers and students to solve the problem of financial difficulties for teachers and students. Seeking opportunities for government and community support, relying on the foundation, financial institutions, enterprises and other organizations to provide innovative financial support for college students, while colleges and universities set up innovative fund committee to supervise the issuance of venture capital funds to ensure the fair use of funds, fair, of the funds to help the system.

\section{B. Make the team as the bridge of innovation activities and platform}

To establish a team, a team for the bridge to link scientific and technological innovation activities and technological innovation platform, play a team advantage, the rational use of members of the knowledge and skills to work together, complement each other to break the limitations of individuals, organized and targeted scientific and technological innovation. Which will help students to provide sufficient self-learning opportunities, good self-learning conditions, rich research resources and a wide range of communication platform, college students in the early theoretical knowledge on the basis of further increase the depth and breadth of college students to penetrate into scientific and technological innovation practice activities, so that students of science and technology innovation closer to life, more suitable for market needs. But also help to improve the students' knowledge structure, promote the development of students' personality, enhance the spirit of innovation and practical ability to form a learning and innovation and practice to promote each other a good atmosphere to the team as a bridge is also conducive to stimulate college students innovation and passion, give students full display of personality, tap the potential of students' innovation, cultivate talent with outstanding practical ability and innovative spirit.

\section{Arrange the instructor scientifically}

Scientific and technological innovation platform of university student needs to be equipped with instructors, needs professional teachers to understand the latest developments in various disciplines, trends and difficult problems better, to sum up and find innovative breakthrough projects. At the same time, the need to give the team suitable for the guidance of teachers, students to carry out scientific and technological innovation activities to guide the work. Furthermore, the teacher belongs 
to the team, help to mobilize the enthusiasm of teachers and students of scientific and technological innovation, training teachers of scientific research, so that they can pay more attention to scientific research and timely understanding of the latest scientific research. To guide students to carry out scientific and technological innovation activities also promote the teacher in-depth study of the problem, careful and meticulous solution, and continue to expand thinking, expand the scientific research side, contribute to the new direction of scientific and technological innovation to the formation of new ideas to promote the vigorous development of scientific and technological innovation.

\section{Improve management system and incentive mechanism of college students innovation}

College of scientific and technological innovation platform in the management of the implementation process, formulate feasible rules and regulations, with the operation and management of the scientific and reasonable mechanism, the establishment of long-term mechanism of college students' scientific and technological innovation, to maximize stimulate enthusiasm to guide the enthusiasm of teachers and students' active participation, give full play to the function of technology innovation platform, and guarantee the students' scientific and technological innovation the long-term effective. The establishment of the corresponding innovation award and punishment system in the university management system, provide a good external environment for the cultivation of comprehensive development, innovation spirit and innovation ability of students, and to take certain measures to strengthen the students' participation in scientific and technological innovation practice enthusiasm and sense of urgency $[8,9]$. At the same time, the student evaluation system should be evaluated in many aspects; training should be conducive to the development of students' comprehensive quality and innovative consciousness and innovative ability as the goal. Student award scholarships and other awards, evaluation standard, should increase the students' innovative consciousness and innovation ability and comprehensive quality of the score proportion; change the current learning ranking as the main criteria of unilateral unfair evaluation.

\section{E. Increase the publicity of scientific and technological innovation}

Strengthening the propaganda of scientific and technological innovation which including use the power of role models and the way of competition to encourage students participate in science and technology innovation activities [10]. And fully use the available platform to carry out a series of Scientific and technological innovation activities such as related lectures, teachers' scientific research projects, laboratory, college students' scientific and technological innovation contest of various levels, social investigation and research, thesis writing, and the proposed project which students are interested in. And then, promoting innovation activities, showing innovation results, which aims at stimulating students' interest in scientific and technological innovation, promoting the scientific and technological innovation consciousness of college students, arousing the enthusiasm of college students to participate in scientific and technological innovation activities.

\section{F. Lead into enterprise and link market}

Colleges and universities establish a platform for scientific and technological innovation, should introduce enterprises, related market business projects to the school, the market demand to the school, so that students have the opportunity to the actual market, participate in the actual business projects to improve their ability, broaden horizons, entrepreneurial experience [11]. Students experience and market demand, not only to promote their own comprehensive development, but also to make innovative technology to enhance the competitiveness of enterprises, scientific research for the community to achieve win. At the same time, the team can more easily cooperate with enterprises and institutions, scientific and technological innovation activities and social, market links, improve the quality and efficiency of scientific and technological innovation. Students use the team to penetrate Scientific and technological innovation into social practice, close contact with the needs of social development, enhance the depth and breadth of college students' scientific and technological innovation, and promote the improvement of college students' comprehensive quality.

\section{Practice RESEARCH ON INNOVATION PlatForm CONSTRUCTION BASED ON TEAM BRIDGE}

Experience has proved that, building scientific and technological innovation platform for college students, with the form of team as a bridge, contributes to improving individual ability in innovation and overall quality, promotes the breakthrough development of the educational mode, deepens the reform of higher education, and eventually promotes the construction of national scientific and technological innovation.

HIT Racing Team (HRT) was built in 2009 by Harbin Institute of Technology at Weihai, consisting of members in majors from all schools. Using knowledge and skills from all members, HRT accomplishes the design, processing, assembly and testing of the vehicle. The endeavor and innovation of all made HRT a successful team.

As one of the earliest teams to participate in Formula Student China (FSC), HRT pursues independent innovation, and applied carbon fiber monocoque while participating in FSC, which was also a domestic initiation. In 2014, HRT independently designed and manufactured full carbon fiber monocoque, which was the only domestic initiation as well. With the advanced carbon fiber monocoque, carbon fiber suspension, carbon fiber axle, full set of aerodynamic packages, and pneumatic shifting, HRT plays a leading role in FSAE in China. HRT has participated in races held in China, Japan and Germany, and presented an outstanding performance in home and abroad. HRT also won awards for 1st in Engineering Design, Autocross, ANSYS Design, Light Weight Design, and many others in FSC, and 3rd in Light Weight Design, CAE Special Award and Best New Entry Award in SFJ and FSG. And in 2016, HRT won two championships in Formula Student Electric China (FSEC) and BAJA Student China (BSC). Honors and awards of HRT are shown in Fig. 1. 


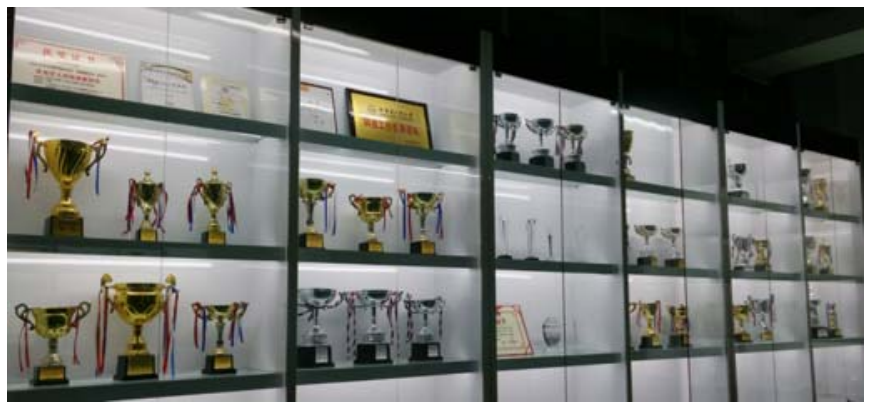

Fig. 1. Honors and awards of HRT.

\section{A. Practice of the team bridge to link innovation activities and platform}

HRT as a bridge to link to scientific and technological innovation activities and platform takes college students Formula One car as the carrier, passing the cultivation of scientific and technological innovation throughout the season. The team focuses on the autonomy, exploratory and cooperative scientific and technological innovation. All team members cooperate with each other and promote each other to carry out scientific and technological innovation, to realize the complementary resources and promote the all-round development of the students.

\section{B. Practice of management system and incentive mechanism}

HRT also established a corresponding management evaluation system to affirm the progress of players, standardized assessment of the achievements of the team members, and the formation of fair and equitable evaluation mechanism to create a positive innovation situation mobilized players to participate in scientific and technological innovation and practical activities of interest.

Racing is the dream of HRT, performance is the pursuit of HRT, and innovation is the soul of HRT. Through the team's training, the team members combined the theoretical knowledge of the classroom and car design in-depth integration, strengthening the practice of scientific and technological innovation, improving the practical ability of players and inspire creativity. A large number of innovative applications applied to the car, which is the source of the team's continuous progress. At the same time, through the HRT team innovation platform experience, the comprehensive ability of college students has been improved.

\section{Practice of the introduction of enterprise and market}

In the process of scientific and technological innovation activities, HIT Racing Team took the car as the carrier, played the team's advantages, made cooperation with enterprises and institutions, and linked the scientific and technological innovation activities with social as well as market. Now the HRT has maintained close contact and deep friendship with other Formula Student China Racing Team, and cooperated with Dynavolt Renewable Energy Technology Co., Ltd,
Weihai Guangwei Group Co., Ltd, Weihai Wanfeng Magnesium S\&T Development Co., Ltd and other related enterprises. Cooperation for the team scientific and technological innovation not only provides new impetus and new energy, improves the quality and effectiveness of scientific and technological innovation, but also to HRT has a broader vision and development prospects.

\section{CONCLUSIONS}

Six methods were proposed to establish scientific and technological innovation platform of college students based on team bridge function. The methods were successfully applied to the HIT Racing Team. HRT is an innovative platform for students with many honors and awards. Practice research results show that the proposed methods can enhance students' science and technological innovation capacity. College student team is beneficial to promote the construction of innovation platform.

\section{REFERENCES}

[1] J. P. Xi, "Sounded the construction of the world science and technology power of the horn," People Daily, 2016-06-01(01). (In Chinese)

[2] R. Thorpe, R. Rawlinson, "Engaging with engagement: how UK business schools could meet the innovation challenge," Journal of Management Development, vol. 33, no. 5, pp. 470-486, 2014.

[3] J. T. Wu, Y. A. Xu, "Domestic and foreign colleges and universities to carry out scientific and technological innovation activities of the status analysis," The new generation, no. 471, pp. 4-6, 2014. (In Chinese)

[4] J. Y. Wei, J. Wang, et al., "Exploration on the engineering college students' cultivation of practical ability of scientific and technological innovation," Education and Teaching Forum Periodicals Agency, no. 50, pp. 151-152, 2014. (In Chinese)

[5] H. Etzkowitz, L. Leydesdorff, "The dynamics of innovation: from national systems and "Mode 2" to a triple helix of university-industrygovernment relations," Research Policy, vol. 29, no. 2, pp. 109-123, 2000.

[6] B. Van Looy, M. Ranga, J. Callaert, et al., "Combining entrepreneurial and scientific performance in academia: towards a compounded and reciprocal Matthew-effect?" Research Policy, vol. 33, no. 3, pp. 425-441, 2004.

[7] J. Tuunainen, T. Knuuttila, "Intermingling academic and business activities: A new direction for science and universities?" Science, Technology, \& Human Values, vol. 34, no. 6, pp. 684-704, 2009.

[8] J. Q. Yan, X. L. Guan, "A Case Study of innovative entrepreneurship system in American, UK and Japanese universities and its enlightenment," Contemporary Education Sciences, no. 21, pp. 48-53, 2015. (In Chinese)

[9] L Bai, Z. Jia, "College students scientific and technological innovation ideological education problem analysis and countermeasures," Theory Research, no. 1, pp. 175-176, 2012. (In Chinese)

[10] H. C. Hsiao, S. C. Chen, C. M. Chou, et al., "Is entrepreneurial education available for graduates?" African Journal of Business Management, vol. 6, no. 15, pp. 5193, 2012.

[11] S. Ollila, K. Williams-Middleton, "The venture creation approach: integrating entrepreneurial education and incubation at the university," International Journal of Entrepreneurship and Innovation Management, vol. 13 , no. 2 , pp. 161-178, 2011. 